\begin{tabular}{|c|c|}
\hline Title & Twenty-Five Y ears of Japanese Peacekeeping Operations and the Self-Defense Forces' Mission in South Sudan \\
\hline Author(s) & Suzuki, Kazuto \\
\hline Citation & $\begin{array}{l}\text { A sia Pacific review, 24(2), 44-63 } \\
\text { https://doi.org/10.1080/13439006.2017.1407534 }\end{array}$ \\
\hline Issue Date & 2017-12-21 \\
\hline Doc URL & http:/hdl .handle.net/2115/74746 \\
\hline Rights & $\begin{array}{l}\text { This is an A ccepted Manuscript of an article published by Taylor \& Francis in A sia Pacific review on 2017-12-21, } \\
\text { available online: http:/Www.tandfonline.com/10.1080/13439006.2017.1407534. }\end{array}$ \\
\hline Type & article (author version) \\
\hline File Information & APR_Dr. Suzuki for review_22 September KS reviewed clean.pdf \\
\hline
\end{tabular}

Instructions for use 


\title{
Twenty-Five Years of Japanese Peacekeeping Operations and the Self-Defense Forces' Mission in South Sudan
}

\author{
KAZUTO SUZUKI
}

ABSTRACT

We would like to receive about 150-200 words here, please.

Japanese participation in Peacekeeping Operations began in the balance between Constitutional and other legal constraints and demand for larger international role in the post-Cold War era. The success of participation in the PKO in Cambodia and East Timor (UNTAC and UNTAET) created opportunities for further participation because of gradual acceptance of the participation of Self-Defense Forces (SDF) in UN PKOs. However, these successes did not change the fundamental constraints of the conditions for participation, namely the Five Principles on PKO participation. The arrival of the second Abe Administration, whose policy objective is to proactively contribute to peace, increased the expectation of taking much larger role of Japan in the UN PKOs, but the SDF participation South Sudan (UNMISS), which faced difficulties due to the lack of firm ceasefire agreement and sudden breakout of civil war, raised questions of whether Abe's policy was too aggressive. With the establishment of Peace and Security legislation, more proactive missions can be taken, but yet, the necessity of national debate for building consensus about participating in PKOs still remains.

After the Second World War, Japan reduced its armaments in accordance with the Constitution of Japan and declared that it would "forever renounce war as a sovereign right of the nation and the threat or use of force as means of settling international disputes." To achieve this goal, the country declared that "land, sea, and air forces, as well as other war potential, will never be maintained. The right of belligerency of the state will not be recognized." By limiting its own military strength to the minimum requirement for self-defense, Japan aimed to be a "peace-loving nation." Since then, Japan's military strategy has remained unchanged, even in the context of the Cold War. The above text, from Article 9 of the Constitution of Japan, was officially proclaimed in 1946 and since the enactment of the Constitution the following year it has remained the same until the present time.

The Self-Defense Forces (SDF), which make up the specified minimum requirement 
for self-defense, were primarily tasked with defending Japanese territory during the Cold War. Even after the Cold War ended, this role did not greatly change. Underlying this situation is Japan's alliance with the US, which originated from the US-Japan Security Treaty. While the SDF are charged only with the defense of Japanese territory, the US military stationed in Japan has deterred invasion from other countries. As a result, Japan has reached the present without the threat of military aggression from other states. Furthermore, the US (or more accurately, a contracting party of the US-Japan Security Treaty) is obligated to jointly deal with armed attacks on Japanese territory, while Japan is not obligated to protect any territories, warships, aircraft, or other properties under US administration. Therefore, although the US-Japan relationship can be considered an alliance, it has been a one-sided alliance. Even during the Cold War, Japan did not participate in wars involving the US (the Korean War, the Vietnam War, and others). Instead, it continued to devote itself only to defending its own territory, in accordance with its discrete right of individual self-defense.

At the end of the Cold War, especially with the start of the Gulf War (the First Iraq War), Japan was compelled to reconsider its military strategy, which had developed in this unique national security environment. The Gulf War provided a major opportunity to realize international peace and security through a UN-centric approach, an aim thus far touted by Japan. Although UN Security Council Resolution 678 "authorize[d] Member States... to use all necessary means," Japan could not assign missions to the SDF beyond the defense of Japanese territory due its discrete right of self-defense as decreed by the Constitution. Therefore, throughout the Gulf War, Japan was limited to providing financial support to the coalition forces. After the war, in accordance with the underwater mine removal provisions of the Self-Defense Forces Law, Japan dispatched the SDF overseas as minesweepers for humanitarian reasons. The inability of Japan to contribute to international efforts outside of this extremely limited capacity triggered discussion about the county's role in the international community. Moreover, in 1991 the Japanese government was stunned when Japan was not included in the 30 countries listed in the two Washington Post advertisements Kuwait took out to thank the coalition.

\section{Establishing the International Peace Cooperation Law}

It was in this context that Japan created the International Peace Cooperation Law. During the outbreak of the Gulf Crisis in October 1990, then Prime Minister Toshiki Kaifu 
submitted the United Nations Peace Cooperation Bill to the Diet. This bill would have created a UN Peace Cooperation Committee under the office of the prime minister, thus allowing Japan to dispatch UN Peace Cooperation Forces, which would be organized outside SDF force structure, to aid in transporting materials, providing medical care, and other peacekeeping tasks. During the Diet's debate on the UN Peace Cooperation Bill, a written response to the October 1990 memorandum stated that supporting actions, even UN actions, using military force were unconstitutional. Additionally, strong opposition from the mass media and public opinion led to the rejection of the bill in November 1990, one month after it was put forward. ${ }^{1}$

However, during the process of attempting to pass this bill, a new idea emerged to permanently modify the structure of the SDF so that Japan could contribute to international causes, rather than dispatching the SDF just for the one-time response to the conflict such as Gulf War. Within this idea was also the proviso that if a strong public and political backlash to sending the SDF overseas was encountered, then the UN Peace Cooperation Forces, half-public, half-private organization, separate from the SDF, could be created to provide a structure through which Japan could contribute to UN peacekeeping and other actions. ${ }^{2}$ The Gulf War, which began in January 1991, was short, with combat lasting for 100 hours from the initial ground fighting until the mission was completed. CNN broadcast live coverage from the conflict areas, which included video of Patriot missiles intercepting Iraqi Scud missiles. These factors gave the Japanese people the impression that this war differed from traditional warfare and showed the overwhelming power of a coalition force led by the United States. The fact that the aforementioned advertisement showing gratitude in the Washington Post did not include Japan also certainly shifted the national mood in Japan. In the end, the nation's understanding of the SDF and the concept of warfare in the modern era underwent significant changes, and discussions about how Japan could contribute to international causes became possible (although opinions for and against Japan's contribution were largely divided).

With these changes in public opinion and the mass media discourse, the Japanese government submitted the International Peace Cooperation Bill (a.k.a. the PKO Cooperation Bill) in December 1991, which permitted Japan to participate in UN peacekeeping operations (PKO) but not coalition forces. The PKO Cooperation Bill was submitted as a revision of the UN Peace Cooperation Bill, and instead of recommending 
the formation of UN Peace Cooperation Forces separate from the SDF, the bill allowed the SDF to participate in UN PKOs. The Japan Socialist Party, which was strongly opposed to sending the SDF overseas, provided thorough resistance to the bill. In response, Secretary General Ichiro Ozawa of the Liberal Democratic Party, who actively supported SDF participation in PKOs under the principle of UN-centric policy, formed a coalition with Komeito and the Democratic Socialist Party, gaining cooperation for the bill.

However, this process necessitated a compromise between the LDP and Ichiro Ozawa's idea of a "normal country," i.e. a country liberated from the Article 9 restrictions of only the discrete right of self-defense instead of a military strategy equivalent to other nations, and the Komeito's and Democratic Socialist Party's idea of protecting the postwar ideal of a "peace-loving country" also actively contributing to international causes. In other words, the LDP hoped that allowing the SDF to accumulate experience and expanding the scope of SDF foreign operations, by dispatching units to UN PKOs, would eliminate national resistance to having the SDF operate overseas. Meanwhile, the Komeito and the Democratic Socialist Party wanted the scope of such foreign operations to remain completely within the framework of UN PKOs, limited to non-military actions focused on logistical support. The result of this compromise was the creation of the severe restrictions known as the Five Principles on PKO Participation.

\section{The Five Principles on PKO Participation}

What is generally referred to as the Five Principles on PKO Participation is explicitly called "the five basic principles governing Japan's participation" within the PKO Cooperation Act, and comprises the following five conditions:

1. A ceasefire must be in place between the parties in the conflict;

2. The parties to the conflict, including countries in the region in which the UN peacekeeping forces will operate, must have given their consent to Japan's participation in the operation and the peacekeeping forces;

3. The activities must be conducted in a strictly impartial manner, with UN peacekeeping forces not showing a bias toward any specific party to the conflict;

4. Japan's participation may be suspended or terminated if any of the above conditions ceases to be satisfied; and

5. The use of weapons shall be limited to the minimum necessary to protect the life or 
person of the personnel ${ }^{3}$.

Until today, these five principles have functioned as the criteria for deciding when Japan will participate in PKOs, and each of these principles are also used by other organizations when creating traditional PKO missions, namely, monitoring ceasefires, observing elections, and ensuring disengagement. In 1958, the second Secretary-General of the United Nations, Dag Hammarskjöld, who is hailed as the father of PKOs, submitted three principles to govern PKOs. In addition to Hammarskjöld's principles of consent, fairness, and not using force of arms except for in cases of self-defense, Japan added the conditions that ceasefire agreements must be in place and that withdrawal of consent is an option, creating the five principles governing PKO participation. Hammarskjöld's three principles were created to provide a stance for actions, which he referred to as Chapter 6 and a Half of the UN Charter. These actions were those for which the Security Council could not proceed due to the give-and-take of the veto right amid the circumstances of the Cold War, and those for which enforcement measures could not be taken in accordance with Chapter 7 of the UN Charter.

In other words, the assumptions made in the PKO Cooperation Act, which includes the five principles governing participation in PKOs as established by Hammarskjöld's three principles, are limited to what can be considered traditional PKOs. Ironically, a few days after the PKO Cooperation Act was enacted in June 1992, then Secretary-General of the UN, Boutros Boutros-Ghali, published his Agenda for Peace. ${ }^{4}$ The Agenda for Peace added new concepts to the traditional model of PKOs, including preventative diplomacy meant to stop disputes from arising. The most prominent issue in relation to the PKO Cooperation Act, however, was the recommendation to use "peace-enforcement units." In contrast to traditional PKOs that assume the existence of a ceasefire agreement, these peace-enforcement units were conceived to enforce peace when such measures could be implemented according to Chapter 7 of the UN Charter. This would be applicable even in cases in which no ceasefire agreement was in place and when the parties involved in the dispute had not agreed to UN intervention. In short, immediately after the PKO Cooperation Act was enacted, Japan was placed into circumstances not anticipated by the act, which forced it to reconsider its relationship with PKOs.

In March 1993, the UN Security Council adopted resolution 814, which applied the idea of peace-enforcement units as described in the Agenda for Peace, to the presently 
occurring second UN action in Somalia (UNOSOM II), authorizing the use of force in resolving the conflict. However, $25 \mathrm{PKO}$ personnel ended up dying in the conflict that broke out in June of the same year, and more soldiers died in combat during a US military action in Somalia separate from UNOSOM II. As a result, the international community became aware of the major risks associated with the idea of peace-enforcement units, and the idea was not implemented again after UNOSOM II.

\section{Success during the Cambodian PKO}

In 1992, the year the PKO Cooperation Act was enacted, the UN was also active in areas outside of Somalia. The long-running Cambodian Civil War ended with the 1991 Paris Peace Accords, and the United Nations Transitional Authority in Cambodia (UNTAC) launched as a completely new type of PKO, in which the UN would temporarily govern Cambodia to ensure that the peace would be permanent. UNTAC was a large-scale government structure with seven divisions that included not only a military division, but also civil administration, civilian police, electoral observer, human rights observer, repatriation, and rehabilitation divisions. It was assigned various tasks, including monitoring the ceasefire, maintaining public order, disarming insurgents and militia, facilitating the repatriation of refugees and evacuees, and holding and monitoring national elections.

This new approach with UNTAC saw Yasushi Akashi, the first Japanese UN staff who also worked as the Under-Secretary-General of Disarmament Affairs, appointed to lead UNTAC as the Special Representative of the Secretary-General. This became the first case in which the SDF was dispatched in accordance with the PKO Cooperation Act. UNTAC had a ceasefire agreement in the form of the Paris Peace Accords, and apart from some members of Pol Pot's faction (the Khmer Rouge), the concerned parties accepted temporary governance by the UN. UNTAC maintained neutrality in the execution of its tasks, including its monitoring of the elections, so all five principles governing PKO participation were met. Not only did Japan make a significant contribution to the effort, with upwards of 600 SDF personnel deployed as ceasefire monitoring and construction units, but the country also sent 75 individuals to the civilian police division and another 23 individuals to the election monitoring division. Tragic sacrifices were made in the service of UNTAC, namely the murders of Haruyuki Takata, who was assigned to the civilian police, and UN volunteer Atsuhito Nakata, who joined the election monitoring 
group. Fortunately, no SDF personnel were killed. Thanks to the significant contributions made to recovery in post-civil-war Cambodia, Japan gained greater self-confidence in its participation in UN PKOs, sweeping away the trauma endured since the Gulf War.

Although the UNTAC PKO was a completely new type of PKO that involved temporary governance, its success was attributable above all to the ceasefire agreement that was in place, in line with traditional PKOs, and the fact that it was mainly a civilian operation. This was in line with the model of providing logistical support, including civilian operation through an organization separate from the SDF, as conceived by the idea of the UN Peace Cooperation Forces outlined in the UN Peace Cooperation Bill. Even though it involved dispatching the SDF, this mission realized the ideal structure of post-ceasefire nation building PKOs. Furthermore, although danger from the armed Pol Pot faction was always present, and skirmishes did occur, the fact that the cease fire was generally observed is also significant. The Cambodian people had high hopes for building the nation after the ceasefire, and UNTAC set clear goals in response to these hopes. Because of this, it was difficult for groups in Japan that opposed sending the SDF overseas to be highly critical of the mission.

By successfully sending the SDF to this PKO in Cambodia, contributions to international causes based on the PKO Cooperation Act gained wide-ranging acceptance in Japan, opening a window for the possibility of future participation in PKOs.

\section{Restrictions in the Five Principles on PKO Participation}

The window for Japanese contributions to international causes, which opened thanks to the country's participation in the Cambodia PKO, did not immediately close. This allowed Japan to participate in a series of UN PKOs, which called attention to the positive results of this participation. Before withdrawing from the Cambodian PKO, Japan took part in logistical support, namely, material support and elections monitoring, for the PKO in Mozambique (ONUMOZ) that took place from May 1993 to January 1995. While the SDF was operating in Mozambique, Japan also took part in the election monitoring PKO in El Salvador (ONUSAL), without having to send the SDF.

However, after the success of the UN PKO in Cambodia, the UN once again encountered a major turning point. The United Nations Protection Force (UNPROFOR), dispatched to the ethnic conflicts occurring in the former Yugoslavia, faced many hardships. In 1991, after the end of the Cold War, tensions among ethnic groups 
intensified in the former Yugoslavia, and a civil war broke out among the republics that comprised the country. Initially, conflict arose between Croatia and Serbia, two of the successor states of Yugoslavia, and in 1992, violent ethnic conflict unfolded in Bosnia-Herzegovina. With the 1992 Maastricht Treaty, the EU expanded the scope of its policy to include diplomacy and security. It considered the ending of the conflict in the former Yugoslavia, an outbreak of war in Europe, and the return of peace to the region as a touchstone for the EU and its newly vested authority. Because of this, it was actively involved in the conflict.

As a result, UNPROFOR took on a markedly military appearance through actions such as establishing a partnership with NATO and UN protected areas (UNPAs) and providing protection with heavily armed PKO units. Thus, despite Yasushi Akashi's assignment as Special Representative of the UN Secretary-General to problems in the former Yugoslavia and Bosnia, and following his successes in the same position in Cambodia, Japan could not send the SDF to the former Yugoslavia, as the mission did not meet the Five Principles on PKO participation. In the end, UNPROFOR was unable to stop violent ethnic cleansing, such as the Srebrenica massacre. Ultimately, however, the conflict in the former Yugoslavia ended thanks to the signing of the Dayton Agreement under US leadership and the deployment of the NATO-led Implementation Force (IFOR).

In the same way, the UN dispatched a PKO mission to Rwanda in 1993 (the United Nations Assistance Mission for Rwanda (UNAMIR)) after Tanzanian intervention brought the ethnic conflict there to a temporary ceasefire. However, the civil war once again erupted following the dispatch. Because of casualties among PKO personnel, the UN Security Council reduced the scope of the Rwanda PKO, despite the requests of the on-site commander. This lead to the PKOs inability to stop the ethnic cleansing atrocities happening before their very eyes. When Canadian Major-General Romeo Dallaire, the force commander at the time, complained about the situation, the world learned about the limits of UN PKOs ${ }^{5}$.

While UN PKOs were facing such major watershed moments, Japan did not change the Five Principles of PKO participation, as outlined alongside with the PKO Cooperation Act. Therefore, these international discussions did not cause significant issues in Japan because of its cautious approach towards participating in PKOs dispatched based on unstable ceasefire agreements. At the same time, the window opened by the Cambodian PKO was rapidly closing, and questions began to arise about the pros 
and cons of limiting Japan's contributions to international causes through the vehicle of traditional PKOs.

\section{Participation in a New Era of PKOs}

After the challenging PKO experiences in the former Yugoslavia and Rwanda, the UN gradually returned to the traditional PKO format, pursuing election and ceasefire monitoring. At this time, the fervor that had risen immediately after the end of the Cold War for building a new international order that was centered on the UN had cooled considerably. Japan clearly found itself in a situation in which it was easier to participate in PKOs. Nonetheless, the enthusiasm for contributing to international causes directly after the Gulf War lessened, as interest grew about issues related to security in Japan and the surrounding region. This stemmed from the 1995 Taiwan Strait Crisis and continued with the 1997 revision to the Guidelines for US-Japan Defense Cooperation (the US-Japan guidelines), as well as the 1998 launch of the North Korean Taepodong missile, which passed over Japanese airspace. However, Japan did participate in the 1996 United Nations Disengagement Observer Force (UNDOF) in the Golan Heights, an early PKO structure in effect since 1974. In this case, the threat of conflict was extremely low, meaning that Japan's contribution consisted of low-risk deployments, such as dispatching commanders or small-scale transport units. (Nevertheless, Japanese personnel were withdrawn in 2013 due to intensification in the Syrian Civil War, which began with the Arab Spring.)

Amid such circumstances, the UN reflected on the PKOs that had developed after the publishing of the Agenda for Peace during the 1990s, forming a Panel on United Nations Peace Operations tasked with reviewing the state of PKOs. This panel published its report, commonly called the "Brahimi Report," in 2000. ${ }^{6}$ In terms of peace-building and disarmament actions using force, the report recommended that the UN must first look at actions from a more realistic and feasibility-focused standpoint that considers risks to PKO personnel. Then, instead of using force for preventative measures or creating peace, it should concentrate on stopping conflicts with diplomacy or mediation. Peace must also be maintained not only by the military but also through cooperation with civilians, and the protection of civilians must be realistic, considering a balance between protection and the safety of PKO personnel. Furthermore, the report led to an expansion of peace-building efforts and the incorporation of specific elements, such as reintegrating 
combatants back into civil society, establishing the rule of law through reinforcement of police and legal systems, and supporting democratization. There were also proposals for building rapid-response systems that could quickly respond with peacekeeping operations and enhance the UN's information gathering and intelligence functions.

Simultaneous with the release of the Brahimi Report, discussions continued on how to protect human rights in nations in a state of civil war or anarchy, especially after the lessons learned from the PKO in Rwanda. In 2000, under the leadership of the Canadian government, the International Commission on Intervention and State Sovereignty (ICISS) was established, and, in 2001, it published a report titled, "Responsibility to Protect." The report explicitly stated that countries have the unmistakable responsibility to protect all populations, and when a country does not fulfill this responsibility, the international community is tasked with it.

As the transition continued from PKOs that accompanied the use of force, such as those seen during the 1990s, to more realistic and responsible peace actions, Japan once again had an opportunity to hope for the type success that it experienced with the Cambodian PKO. That opportunity came with its participation in the 1999 United Nations Transitional Administration in East Timor (UNTAET). Like UNTAC in Cambodia, UNTAET was based on a relatively firm peace accord and was tasked with not only military or security maintenance missions but also various other missions, including establishing effective governance, supporting the development of civil and social services, humanitarian aid, ensuring the coordination and provision of recovery and developmental aid, and helping to train leaders capable of self-governance. Japan participated in UNTAET from 2002 until 2004. It dispatched field commanders and engineering units with 400-600 personnel and performed tasks to help East Timor become independent.

The UNTAET action was the perfect opportunity for Japan to ask how it would be involved in the new era of peace actions, a continuation of part of the original discussion on how Japan would contribute to the international community. However, in asking how Japan would be involved in the Afghanistan War, which followed the multiple simultaneous terror attacks in the US that occurred on September 11, 2001, and the Iraq War, which started in 2003, the problem of Japan's contribution to international causes was replaced with its cooperation in the US War on Terror. In this context, interest in questions related to UN peace actions waned. 


\section{PKO participation from an actively pacifist approach}

Since its participation in the PKO in East Timor, Japan sent only six military observers to the United Nations Mission in Nepal (UNMIN), from 2007 to 2011, and two commanders to the United Nations Mission in Sudan (UNMIS), from 2008 to 2011. It has continued to send fewer than 100 personnel to all UN PKOs, including UNDOF in the Golan Heights, to which it contributed since 1996. In 2010, Japan sent a unit of 350 engineering personnel for disaster recovery to the United Nations Stabilization Mission in Haiti (MINUSTAH), which was tasked with maintaining public order and restoring the country after the major 2010 earthquake. This unit was active until 2012, but as this mission focused on post-earthquake rebuilding, it did not really raise awareness about peacekeeping operations. Also, after the Great East Japan Earthquake and the Fukushima Daiichi nuclear accident that happened in March 2011, domestic coverage regarding the $\mathrm{UN}$ activities in Haiti diminished. ${ }^{8}$

However, after the LDP returned to power in late 2012, and Shinzo Abe became prime minister, the situation has again changed significantly. In 2013, the National Security Council was established, and simultaneously, the National Security Strategy was publicly announced. ${ }^{9}$ Japan touted the basic principle of its National Security Strategy to be that "Japan will continue to adhere to the course that it has taken to date as a peace-loving nation, and as a major player in world politics and economy, contribute even more proactively in securing peace, stability, and prosperity of the international community, while achieving its own security as well as peace and stability in the Asia-Pacific region, as a "Proactive Contributor to Peace" based on the principle of international cooperation." This concept of being a "proactive contributor to peace based on the principle of international cooperation" is not just the focus of the diplomatic security policy of the Abe administration. It is also intended to clarify Japan's role in the post-Cold War international community, a position for which Japan has been searching since the Gulf War.

Naturally, at the heart of being a "proactive contributor to peace based on the principle of international cooperation" is active participation in UN PKOs. Indeed, there are several ways to proactively contribute to peace, such as participating in non-UN peacekeeping operations or cooperating with international anti-terror activities, but Japan places UN PKOs at the heart of its contributions. An example of Japan's proactive 
contributions to peace is sending the SDF to the United Nations Mission in South Sudan (UNMISS). This was highlighted by Prime Minister Abe during his address at the Shangri-La Dialogue in May 2014. ${ }^{10}$

\section{PKOs based on unstable ceasefire agreements}

In an effort to establish peace and security in the Republic of South Sudan, which achieved independence from Sudan in July 2011, UNMISS began in 2011 as a UN PKO to aid the Republic's development. In November 2011, the DPJ administration at the time issued a cabinet decision to dispatch engineering and other SDF units, who began their mission in January 2012. The main force was an engineering unit of at most 300 personnel, with the primary duties of building infrastructure in the capital Juba and the surrounding areas. There was also a unit (of at most 40 personnel) that coordinated efforts with the UN and local governmental agencies, as well as units from the Maritime SDF and the Air SDF to provide transportation and supplies for the other units. Such large-scale participation in a PKO had not occurred since UNTAET in East Timor, and together with UNTAC in Cambodia, this action embodied a representative PKO for Japanese participation.

In the cases of UNTAC and UNTAET, while combat in the form of minor skirmishes did occur, ceasefire agreements were generally observed, and the dispatched SDF units did not face many situations with dangerous conditions. However, circumstances were significantly different for UNMISS in South Sudan. The Abyei District straddles the border between South Sudan and Sudan, a region that encompasses oil fields. When South Sudan became independent from Sudan in July 2011, the countries agreed that the Abyei District belonged to Sudan, but the Heglig oil field is not contiguous with the district, so no clear agreement about its ownership was in place. Sudan, which asserts ownership of the district, used military force to take control of the Heglig oil field in April 2012, and both countries engaged in combat. Because this combat was localized in the district far removed from the South Sudan capital Juba, where Japan's SDF was working, harm was not likely to come to the Japanese PKO unit. However, when the Sudanese Army declared that it would march toward Juba, it became highly likely that the ceasefire agreement would be broken. Ultimately, this border dispute between Sudan and South Sudan resulted in a temporary conclusion of hostilities in January 2013, after the two sides reached a tentative agreement regarding the ownership of the oil field in Addis 
Ababa, Ethiopia.

Nonetheless, the next conflict was not an international confrontation between Sudan and South Sudan, but the outbreak of civil war due to a power struggle in South Sudan. In December 2013, armed conflict arose between the Sudan People's Liberation Movement (SPLM), which played a leading role in South Sudanese independence, and President Kiir's presidential guards. The SPLM, which mostly comprises the Nuer people, had supported the former Vice President Machar, who is of Nuer descent. President Kiir, on the other hand, was of Dinka descent. The coup d'état was characterized by being both a power struggle between president and vice president and an ethnic conflict between the Dinka and the Nuer peoples. The direct cause of the coup d'état was that President Kiir removed Machar from the office of the vice president, but there had also been dissatisfaction among the SPLM regarding the lack of sufficient benefits under the Kiir administration after South Sudanese independence.

The civil war that began with this coup d'état was not only fought in the capital Juba but across the whole of South Sudan. The Intergovernmental Authority on Development (IGAD), which comprises several East African countries, intervened, and a ceasefire agreement was signed in January 2014. However, the fighting did not stop, and South Sudan remained in a de facto state of civil war. 


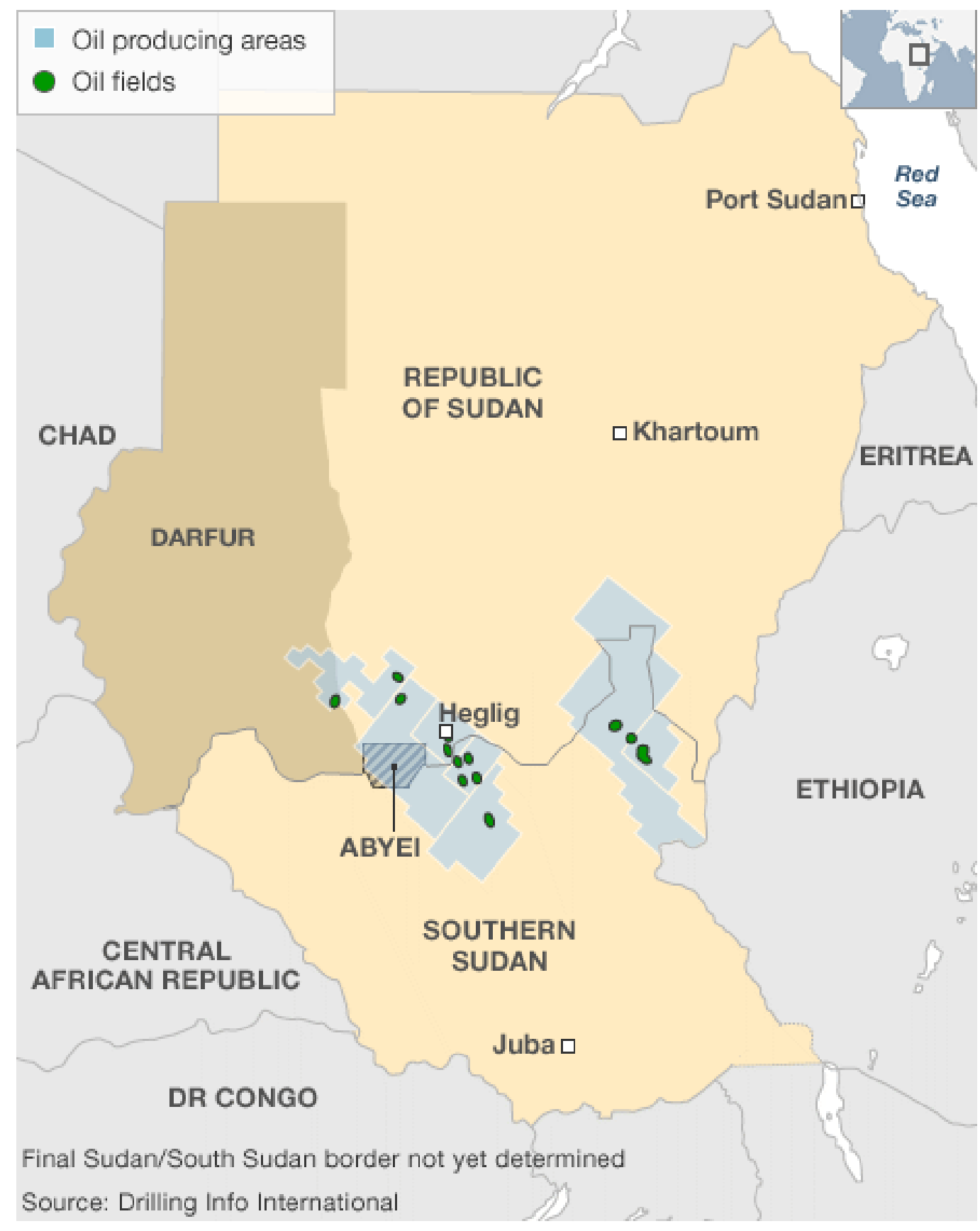

Figure 1: The Heglig Oil Field and the Abyei District in the Border Regions of Sudan and South Sudan

Source: Gurtong Trust

http://www.gurtong.net/ECM/Editorial/tabid/124/ctl/ArticleView/mid/519/articleId/6838/South-Sudan-to -withdraw-troops-from-Heglig-oil-field.aspx

\section{Providing arms to a South Korean Unit}

With the outbreak of the coup d'état in December 2013, the Japanese SDF unit was not 
directly harmed, but there was fear that UNMISS units would be involved in the conflict. Under those circumstances, a South Korean unit made a request to UN headquarters for additional ammunition to handle the conflict, and the UN passed the request for support to the Japanese government. Lending and borrowing ammunition among PKO units was not necessarily unusual, but Japan was faced with a difficult decision. Because of Japan's Three Principles on Arms Exports, the transfer of arms to other countries must be restrained.

The Three Principles on Arm Exports are the three principles established in 1967 by the cabinet of then Prime Minister Eisaku Sato, and they specifically prohibit the export of arms to (a) communist bloc countries, (b) countries subject to arms exports embargo under the United Nations Security Council's resolutions, and (c) countries involved in or likely to be involved in international conflicts. In 1976, Prime Minister Miki's cabinet established an updated version of the Three Principles on Arm Exports, which stated that (1) arms exports to the target countries in the three principles would not be allowed, that (2) arms exports to other regions would be restrained in conformity with the spirit of the Constitution, and that (3) the export of equipment related to the production of arms would be treated as equivalent to the export of arms. Thus, anything classified as arms had the imposed restriction that Japan must restrain any exports, even to countries that are not communist bloc countries, countries subject to arms embargo, or countries involved in conflicts. These Three Principles on Arm Exports have been supported by the people of Japan, who will not allow their country with its peace-loving constitution become a "merchant of death." Furthermore, Japan has less experience than other countries in waging war, making it unlikely that high-priced Japanese weapons could be exported. Because of this, even though the industrial world would likely approve of the export, the Three Principles on Arm Exports set Japan as an example of a peace-loving nation, and, this reasoning functioned as a solid quasi-constitutional understanding. ${ }^{11}$

Hence, providing ammunition to the South Korean unit's dilemma required a prudent response, as Japan also feared the flood of criticism were it to violate the Three Principles on Arm Exports. However, the Abe administration, stressing Japan's proactive contributions to peace, decided to transfer 10,000 rounds of ammunition, arguing that "given the urgent necessity and the highly humanitarian nature of the situation," 12 protecting the lives of the South Korean units and the 15,000 refugees they safeguarded superseded the importance of the Three Principles on Arm Exports. 
Nevertheless, based on government statements from past Diets, the request to supply arms or ammunition from the United Nations was completely unexpected. In the past, even if they had received such a request, they would have refused. The opposition parties in Japan used this inconsistency between past government statements and the current administration's decision to question the decision itself. Furthermore, in South Korea, receiving a supply of ammunition from the Japanese SDF was roundly criticized for being linked to an exercise of the right to collective self-defense, a subject increasingly debated in Japan. ${ }^{13}$ Because of this, South Korea supplied its units with the ammunition and returned the 10,000 rounds of ammunition received from Japan.

This incident also showed how the question of Japan's contributions to international causes had not changed much since the Gulf War. Japan desires to contribute to the building and maintenance of the international order and to earn a position of honor within the international community. Nonetheless, it has faced various constitutional and quasi-constitutional restrictions, while also feeling pressure from other countries, such as South Korea's concerns about Japan's rearming. Combined, this means that Japan must act with extremely limited options. Moreover, the official relationship between Japan and South Korea, guided by issues such as the problem of interpretation of history and perception of the SDF, clearly has had a far greater political impact than any praise Japan may have received for its involvement in various PKOs, regardless of its track record.

Even the SDF soldiers who are deployed to PKOs have experienced challenges associated with acting within the framework of the mission and its operations, which is limited by legal restrictions and political pressures. Although they may not encounter any problems when stable ceasefires are maintained, officers and soldiers both face high-pressure situations and complex decisions due to the considerable behavioral restrictions present when unanticipated chaos erupts, such as during the coup d'état in December 2013. Thus far, Japan's participation in PKOs has been limited to traditional models based on the five principles governing PKO participation. Even when participating in new types of PKOs, such as UNTAC and UNTAET, the government has chosen to only pursue operations in which a stable ceasefire agreement acts as a foundation. Even so, the South Sudan PKO forced a problem below the surface to suddenly flare up. 


\section{Peace and security legislation}

Facing such fundamental questions, the state of Japan's participation in PKOs has been taken up as a major issue in the debate surrounding peace and security legislation, a key policy of the Abe administration. In February 2013, a mere two months after the administration took power, experts formed the "Council on Reconstruction of a Legal Basis for Security" (commonly, the "security legislation council"), who then issued a report in May 2014. ${ }^{14}$ The report looked at various issues, such as the emergence of China as a major military power and the problem of North Korea developing nuclear weapons and missiles, and it laid out the legal situation surrounding security in Japan. The main focus of the report was the possibility of exercising of the right of collective self-defense and the extent to which this right could be exercised. However, a point made in the report relevant to this study is that participation in UN PKOs is not prohibited by Article 9 of the Constitution. The report recommended that the Japanese government recognize the use of arms for self-defense and in situations such as rush-and-rescue missions targeting personnel and units of other countries. Additionally, it suggested that the Japanese government consider the propriety of policies, without imposing legal restrictions on logistical support for actions of other countries.

After receiving the security legislation council's report, the government submitted 11 bills to the Diet, including a revision of the PKO Cooperation Act, but considering the strong objections from opposition parties, deliberation on the bill took a considerable amount of time. The revision to the PKO Cooperation Act that was enacted in September 2015 not only included the aforementioned rush-and-rescue missions, but also eased restrictions on the use of arms in the joint defense of encampments, so that Japan's SDF could act in concert with other countries.

Such relaxing of legal restrictions aimed to lower the hurdles associated with participating in UN PKOs, with the aim of realizing the ideal of proactively contributing to peace. Nevertheless, the bill faced strong resistance from opposition parties during deliberations. In a major shift, even the coalition party Komeito had a negative opinion of the bill. Furthermore, there was also harsh criticism about the bill from public opinion and the mass media. This was despite the fact that the most important change to the Five Principles of PKO participation, the provision on rush-and-rescue missions, was nothing but an additional point, and the original principles, such as the need for a ceasefire agreement, the consent principle, and the neutrality principle, continued to apply. From 
the perspective of proactively contributing to peace, the five principles governing PKO participation held as conditions for participating in traditional PKOs, but these conditions became too high of a hurdle for participating in modern PKOs. However, due to concerns about the safety of SDF soldiers dispatched as PKO personnel and their involvement in local conflicts, the ruling coalition agreed to not make any major changes to the five principles governing PKO participation when revising the PKO Cooperation Act.

\section{Withdrawal from South Sudan}

The revised PKO Cooperation Act went into effect in March 2016, a period in South Sudan when the confrontation between President Kiir's supporters and Vice President Machar's supporters once again intensified. At this time, the situation continued to be critical. In July 2016, armed conflict between the two parties began, and South Sudan was thrust into a state of civil war. Moreover, the armed conflict mainly took place in the capital Juba, placing the SDF encampment in a dangerous situation, likely to be caught between a hail of bullets on both sides.

At the time, staff from the Japan International Cooperation Agency (JICA), who had been working in South Sudan, fled to the SDF encampment and were transported to Djibouti via SDF transports. However, Ambassador Kiya, the Ambassador to South Sudan, stayed at the camp, so the SDF was charged with defending not only themselves but also their countrymen. The fighting around the camp became intense, and a Bangladeshi unit stationed in the same camp suffered casualties.

Meanwhile, after this incident, a situation referred to as the "daily report affair" occurred. The "daily report affair" was multifaceted, but one aspect was that whenever the word "combat" was used in the daily reports written by the SDF soldiers to describe the daily situation of their deployment, the Ministry of Defense would replace the word with the phrase "armed conflict ${ }^{15 ،}$ in their summaries of the reports. Another aspect was that it became clear that although the government was claiming that the daily reports had been destroyed, they were actually being kept in storage, which raised questions about whether the government was trying to hide the reality that the SDF had seen combat. Furthermore, there were criticisms about the government's approach of preferring to suppress information over storing documents, and some questioned whether the Minister of Defense was directly involved in the so-called suppression of information.

The main issue in the daily report affair was that the Ministry of Defense, in violation 
of one of the five principles governing PKO participation, tried to avoid recalling the SDF units, even though a ceasefire agreement was no longer in place. When the country was plunged into a state of civil war in July 2016, and fighting broke out near the encampment, the act of replacing "combat" with "armed conflict" was a nuance illustrating that the ceasefire agreement was just barely being maintained. This was considered an intentional act to avoid withdrawing the SDF units. Additionally, while the true intent of the Minister of Defense initially stating to the Diet that "the daily reports were destroyed" is unclear, it is possible that the motivation was to not disclose that the word "combat" was being used.

During the disputes in the Diet surrounding the daily report affair, the Abe cabinet issued a decision to withdraw the SDF from South Sudan in March 2017. By May 2017, all units, barring the force commander, were removed. The government has stated that this withdrawal "marks a definite end"16 to the action in South Sudan and that it will continue to contribute to UN PKOs based on the principle of proactively contributing to peace. However, there is no mistaking that the intensification of the fighting in South Sudan and the pursuit of the daily report affair in the Diet influenced the decision to withdraw, resulting in a major impact on Japan's future participation in UN PKOs.

\section{Conclusion}

In this paper, we reconstructed Japan's PKO actions since the time of the Gulf War, looking back from that time until the present withdrawal from South Sudan. Based on these observations, we can make several conclusions.

First, Japan faces strong legal restrictions, and powerful norms have been erected due to these restrictions. The Gulf War trauma that resulted from solely financial support not being regarded as contribution to international causes opened the possibility of human resource contributions instead. Additionally, the PKO Cooperation Act opened the option of participating in UN PKOs. This occurred despite the significant resistance these changes encountered. However, against the backdrop of constitutional restrictions and criticisms from the public and the mass media, the government developed a compromise with Komeito and the Democratic Socialist Party, leading to the only restrictions for PKO participation being the five principles governing PKO participation. Because of the existence of these restrictions, in South Sudan, where the ceasefire agreement was unstable and civil war broke out, the dilemma between reality and legal restrictions triggered the daily report affair. The withdrawal from South Sudan, which was influenced 
by the daily report affair, means that there will be even higher hurdles for participation in future PKOs. There will likely be a stronger tendency to participate in low-risk PKOs that have ceasefire agreements in place, rather than to promote proactive contributions to peace by revising the five principles regarding PKO participation.

Second, due to the accumulated successes of missions in Cambodia and East Timor, there is a deeper understanding of PKOs in Japan, and the strong resistance encountered when the PKO Cooperation Act was enacted no longer exists. In fact, the Japanese public has praised Japan's proactive contributions to international causes, giving the mission and raison d'être of the SDF even more significance. Furthermore, in combination with disaster relief missions, such as those seen during the Great East Japan Earthquake, international peacekeeping actions and missions contribute to society's appraisal of the SDF itself. As a result, these factors have become the foundation for the National Security Strategy in Japan, vis-a-vis the changes in the security environment that have occurred since the end of the Cold War. Consequently, they have raised Japan's confidence in the SDF.

However, looking only at Japan's participation in PKOs for the past 25 years in terms of the initial question of whether Japan's contributions to international causes have improved its position in the international community and enhanced its role in international peace and security, it is difficult to say that these goals have been achieved.

During the transition from traditional PKOs to modern PKOs, in which the exercise of force is possible, middle powers, such as Canada and various European countries, are reducing their involvement in PKOs. Resultantly, PKOs have changed to primarily consist of units from developing countries, leading to a change in the international evaluation of contributions to PKOs. Additionally, UN interventions in ethnic conflicts and human rights violations have been called out by the Brahimi Report. This report points to the tendency of these missions to repeatedly encounter challenges due to inadequate mandates and insufficient equipment and training. Additionally, it notes the fact that UN interventions often do not lead to improved positions in the international community. Furthermore, international problems of peace and security have shifted to problems that cannot be resolved with PKOs, such as those involving anti-terror policies and North Korean nuclear developments. This is another factor as to why UN interventions have found it difficult to achieve their goals.

In this modern security environment, it has come time for Japan to once again discuss 
how it will continue contributing to PKOs, whether its participation is possible in light of the dynamically changing roles and missions of PKOs, and what Japan hopes to achieve by contributing to PKOs. How will Japan realize the fundamental principle of its National Security Strategy of proactively contributing to peace based on the principle of international cooperation? To what extent must Japan take risks for this purpose? Such discussions are important because recent experiences in situations such as the South Sudan PKO remain current. Without these discussions, Japan may be unable to contribute to anything but traditional PKOs, making it difficult to realize its proactive contributions to peace based on the principle of international cooperation.

\section{About the author}

We would like to receive about 150-200 words here, please. Kazuto Suzuki is Professor of International Politics at Public Policy School of Hokkaido University, Japan. He graduated Department of International Relations, Ritsumeikan University, and received Ph.D. from Sussex European Institute, University of Sussex, England. He has worked as the Associate Professor at the University of Tsukuba from 2000 to 2008, and moved to Hokkaido University. He also spent one year at Woodrow Wilson School of Public and International Affairs at Princeton University from 2012 to 2013 as visiting researcher. He served as an expert in the Panel of Experts for Iranian Sanction Committee under the United Nations Security Council from 2013 to July 2015. He has conducted researches from International Political Economy perspective in Space Policy, together with nuclear energy policy, export control, counter-terrorism, non-proliferation, and policies on market regulation. He has contributed to the drafting the Basic Space Law of Japan, and serves as a member of Sub-committees of industrial policy and space security policy of National Space Policy Commission. His recent work includes Space and International Politics (2011, in Japanese, awarded Suntory Prize for Social Sciences and Humanities), Regulatory Power of EU (editor 2012, in Japanese), Policy Logics and Institutions of European Space Collaboration (2003) and many others.

\footnotetext{
${ }^{1}$ Toshiya Nakamura, "Mass Media and Policy Making—Rejecting the UN Peace Cooperation Bill," Journal of the Faculty of Global Communication, Siebold University of Nagasaki 6 (2005): 199-212. $\frac{}{2}$ Takayoshi Shoji, "Conflict Surrounding the Creation of Legislation: The Ministry of Foreign Affairs and the Process of Creating the UN Peace Cooperation Bill," Annual Report of the Japan Political Science Association: Electoral Politics During Administration Change Vol. 2 (2011): 206-227.

${ }^{3}$ Regarding the fifth principle, the revised 2015 International Peace Cooperation Act (the PKO

Cooperation ACT) includes an added provision on "rush-and-rescue defense," which states that "in
} 
situations in which the consent for Japan's participation is confirmed to remain stable, the use of weapons beyond self-preservation and armed defense is permitted when carrying out any form of security mission and rush-and-rescue defense."

4 Secretary-General of the United Nations, Agenda for Peace, A/47/277, 17 June 1992. http://www.un-documents.net/a47-277.htm. Coincidentally, it is said that the motive for hurrying through the passage of the PKO Cooperation Law was that the Japanese government wanted it enacted before the Agenda for Peace was published.

5 Romeo Dallaire, Shake Hands With the Devil: The Failure of Humanity in Rwanda, Vintage Canada, 2004.

6 "Report of the Panel on United Nations Peace Operations," A/55/305-S/2000/809, 2000.

http://www.un.org/documents/ga/docs/55/a55305.pdf

${ }^{7}$ International Commission on Intervention and State Sovereignty, Responsibility to Protect, Report of the International Commission on Intervention and State Sovereignty, December 2001.

http://responsibilitytoprotect.org/ICISS\%20Report.pdf

${ }^{8}$ Meanwhile, the Stabilization Mission in Haiti was implicated in a post-earthquake cholera outbreak, and the UN was accused of not taking sufficient action to prevent the spread of infection. In 2016, UN

Secretary-General Ban Ki-moon accepted this responsibility and apologized, but this issue received almost no coverage in Japan.

${ }^{9}$ National Security Strategy, December 17, 2013.

http://www.cas.go.jp/jp/siryou/131217anzenhoshou/nss-e.pdf

${ }^{10}$ The 13th IISS Asian Security Summit -The Shangri-La Dialogue-Keynote Address by Shinzo ABE, Prime Minister, Japan, "Peace and prosperity in Asia, forevermore, Japan for the rule of law, Asia for the rule of law, and the rule of law for all of us", May 30, 2014.

http://www.mofa.go.jp/fp/nsp/page4e_000086.html

11 Peter J. Katzenstein, Cultural Norms and National Security: Police and Military in Postwar Japan, Cornell University Press, 1998

${ }^{12}$ Contribution in Kind to the United Nations Mission in the Republic of South Sudan (UNMISS)

(Statement by the Chief Cabinet Secretary), December 24, 2013.

http://japan.kantei.go.jp/96_abe/decisions/2013/1224unmiss_ccs_e.html

13،'South Korean Government Refutes Concerns about Ammunition Support from Japan," Yonhap News 24 Dec. 2013.

http://japanese.yonhapnews.co.kr/headline/2013/12/24/0200000000AJP20131224003000882.HTML

${ }^{14}$ Report of the Council on Reconstruction of a Legal Basis for Security, 25 May 2014. http://www.kantei.go.jp/jp/singi/anzenhosyou2/dai7/houkoku.pdf

${ }^{15}$ The entire text of the daily reports from July 11-12, 2016, was published following a

freedom-of-information request. Kota Hatachi, "Has the SDF Engaged in Combat in South Sudan? Full

Text of Redacted Daily Reports Publicized,” Buzzfeed News, 9 Feb. 2017. https://www.buzzfeed.com/jp/kotahatachi/south-sudan-nippo?utm_term=.hbOkkkkmZO\#.fuGPPPPAw8

16“"The Fundamental Reasoning Behind the End of SDF Construction Unit Activities in UNMISS," 10 Mar. 2017. http://www.cas.go.jp/jp/houdou/pdf/20170310shiryou.pdf 